\title{
SOUTHERN OCEAN OBSERVING SYSTEM (SOOS): RATIONALE AND STRATEGY FOR SUSTAINED OBSERVATIONS OF THE SOUTHERN OCEAN
}

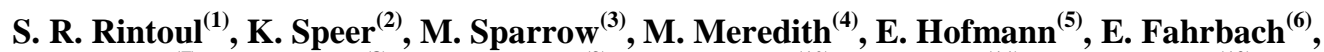
C. Summerhayes ${ }^{(7)}$, A. Worby ${ }^{(8)}$, M. England ${ }^{(9)}$, R. Bellerby $^{(10)}$, S. Speich $^{(11)},(2)$, D. Costa ${ }^{(12)}$, J. Hall $^{(13)}$, M. Hindell ${ }^{(14)}$, G. Hosie ${ }^{(15)}$, K. Stansfield ${ }^{(16)}$, Y. Fukamachi ${ }^{(17)}$, T. de Bruin ${ }^{(18)}$, A. Naveira Garabato ${ }^{(16)}$, K. Alverson ${ }^{(19)}$, V. Ryabinin ${ }^{(20)}$, H. C. Shin ${ }^{(21)}$, S. Gladyshev ${ }^{(22)}$

(1) CSIRO (Commonwealth Scientific and Industrial Research Organisation) and ACE CRC (Antarctic Climate \& Ecosystems Cooperative Research Centre), GPO Box 1538, Hobart, Tasmania 7001 Australia, Email: steve.rintoul@csiro.au

${ }^{(2)}$ Florida State University, 600 W. College Avenue, Tallahassee, FL 32306-2840 USA Email: kspeer@ocean.fsu.edu

(3) SCAR (Scientific Committee on Antarctic Research), Lensfield Road, Cambridge, CB2 1ER, UK, Email: mds68@cam.ac.uk

${ }^{(4)}$ BAS (British Antarctic Survey), High Cross, Madingley Road, Cambridge, CB3 OET, UK, Email: mmm@bas.ac.uk

${ }^{(5)}$ Old Dominion University, CCPO (Center for Coastal Physical Oceanography), Norfolk, Virginia, 2352, USA, Email: hofmann@ccpo.odu.edu

${ }^{(6)}$ AWI (Alfred Wegener Institute), Bussestrasse 24 D-27570 Bremerhaven, Germany, Email: Eberhard.Fahrbach@awi.de

(7) SCAR (Scientific Committee on Antarctic Research), Lensfield Road, Cambridge, CB2 1ER, UK Email: cps32@cam.ac.uk

${ }^{(8)}$ AAD (Australian Antarctic Division) and ACE CRC (Antarctic Climate \& Ecosystems Cooperative Research Centre),

University of Tasmania, Private Bag 80, Hobart, 7001, Australia, Email: A.Worby@utas.edu.au

${ }^{(9)}$ UNSW (University of New South Wales), Sydney NSW 2052 Australia, Email: M.England@unsw.edu.au

${ }^{(10)}$ Bjerknes Center for Climate Research, Allegaten 55, 5007 Bergen, Norway,

Email: Richard.Bellerby@bjerknes.uib.no

${ }^{(11)}$ LPO (Laboratoire de Physique des Océans), UMR6523, UFR Sciences, 6, av Le Gorgeu C.S. 93837, 29238 Brest Cedex 3 France, Email: speich@univ-brest.fr

${ }^{(12)}$ University of California, Santa Cruz, 1156 High Street, Santa Cruz, Ca 95064 USA, Email: costa@biology.ucsc.edu

${ }^{(13)}$ NIWA (National Institute of Water \& Atmospheric Research), 301 Evans Bay Parade, Hataitai, Private Bag 14901, Wellington 6021, New Zealand, Email: j.hall@niwa.co.nz

(14) University of Tasmania, Hobart, Tasmania, Australia, Email: mark.hindell@utas.edu.au

${ }^{(15)}$ Australian Antarctic Division, 203 Channel Highway, Kingston, Tasmania 7050, Australia, Email: ghosie@aad.gov.au

${ }^{(16)}$ National Oceanography Centre, Waterfront Campus, European Way, Southampton SO14 3ZH United Kingdom, Email: kate.stansfield@noc.ac.uk, acng@noc.soton.ac.uk

${ }^{(17)}$ Institute of Low Temperature Science, Hokkaido University, Kita-19, Nishi-8, Kita-ku, Sapporo 060-0819, Japan, Email: yasuf@lowtem.hokudai.ac.jp

${ }^{(18)}$ NISR (Netherlands Institute for Spatial Research), Landsdiep 4 t'Horntje, Postbus 59, 1790 AB Den Burg, Texe, Noord Holland, Netherlands, Email: taco.de.bruin@nioz.nl

${ }^{(19)}$ IOC (Intergovernmental Oceanographic Commission), 1 rue Miollis, 75732 Paris Cedex 15, France, Email: k.alverson@unesco.org

${ }^{(20)}$ WCRP(World Climate Research Programme) c/o World Meteorological Organization, 7bis, Avenue de la Paix, 1211 Geneva, Switzerland, Email: vryabinin@wmo.int

${ }^{(21)}$ KOPRI(Korea Polar Research Institute), Songdo Techno Park Get-perl Tower 19F, 7-50, Songdo-dong, Yeonsu-gu, Incheon 406-840, Korea, Email: cshin@kopri.re.kr

${ }^{(22)}$ Shirshov Institute of Oceanology, 30, 1 Liniya, Vasilievskiy Ostrov, 199053 St Petersburg, Russia,

Email: Gladyshev@sio.rssi.ru 


\section{ABSTRACT}

By connecting the ocean basins and the upper and lower limbs of the ocean overturning circulation, the Southern Ocean plays a critical role in the global ocean circulation, biogeochemical cycles and climate. Limited observations suggest the Southern Ocean is changing: the region is warming more rapidly than the global ocean average; salinity changes driven by changes in precipitation and ice melt have been observed in both the upper and abyssal ocean; the uptake of carbon by the Southern Ocean has slowed the rate of climate change but increased the acidity of the Southern Ocean; and there are indications of ecosystem changes. However, the short and incomplete nature of existing time series means that the causes and consequences of observed changes are difficult to assess. Sustained, multi-disciplinary observations are required to detect, interpret and respond to change. The Southern Ocean Observing System (SOOS) will provide the long-term measurements required to improve understanding of climate change and variability, biogeochemical cycles and the coupling between climate and marine ecosystems.

\section{RATIONALE AND KEY SCIENCE CHALLENGES}

As a result of the unique geography of the Southern Ocean, the region has a profound influence on the global ocean circulation and the earth's climate. The planet's largest current, the Antarctic Circumpolar Current (ACC), carries climate signals from one ocean basin to another and isolates the cold polar region from the warmer subtropics. The region exhibits one of the largest albedo variations on Earth, associated with the seasonal expansion and contraction of the Antarctic sea-ice. The greatest potential for sea-level rise lies in the ice sheets of western Antarctica, and the most likely mechanism for melting them lies in the upwelling of warm deep water onto the Antarctic shelf. The upwelling water is also the source of nutrients for much of the world's oceans, controlling global productivity. These phenomena and others illustrate the dramatic role that the Southern Ocean plays in Earth system and highlight the need to understand its sensitivity and feedback to future climate change.

The ACC acts as a regulator for Earth's climate in several ways. The absence of land barriers in the latitude band of Drake Passage allows a circumpolar current to exist, connecting the ocean basins. As a consequence, the global-scale overturning circulation is dynamically linked to the state of the ocean itself, in contrast to the northern hemisphere where land barriers can support currents transporting heat directly to high latitudes. The strong north-south tilt of density surfaces associated with the eastward flow of the ACC exposes the deep layers of the ocean to the atmosphere at high southern latitudes. Wind and buoyancy forcing at these isopycnal outcrops transfers water between density layers, and connects the deep global ocean to the surface layers; eddy fluxes of mass, heat, momentum and tracers play a central part in the vertical and meridional transfer associated with the overturning. In this way, the Southern Ocean controls the connection between the deep and upper layers of the global overturning circulation and thereby regulates the capacity of the ocean to store and transport heat, carbon and other properties that influence climate and global biogeochemical cycles [44].

The upwelling branch of the overturning circulation in the Southern Ocean returns carbon and nutrients to the surface layer, while the downwelling branches transport heat, carbon and other properties into the ocean interior. The balance between upwelling and outgassing vs subduction of carbon into the ocean interior determines the strength of the Southern Ocean sink of $\mathrm{CO} 2$. This balance depends on wind forcing and eddy dynamics of the ACC. The Southern Ocean contributes more than any other latitude band to the ocean storage of the excess heat and carbon added to the earth-atmosphere system by human activities than any other latitude band [33] and [47]. About $40 \%$ of the total global ocean inventory of anthropogenic carbon dioxide is found south of $30^{\circ} \mathrm{S}$ [47]. Export of nutrients by the upper limb of the overturning circulation ultimately supports $75 \%$ of the global ocean primary production north of $30^{\circ} \mathrm{S}$ [48].

Climate and sea-level rise are influenced strongly by ocean - cryosphere interactions in the Southern Ocean. Changes in sea ice extent or volume will result in changes in the Earth's albedo, oceanic water mass formation rates, air-sea exchange of gases such as carbon dioxide, and habitat for organisms from microbes to whales. Melting of floating glacial ice by warm ocean waters influences the high latitude freshwater budget and stratification and may affect the stability of the Antarctic ice sheet and the rate at which glacial ice flows into the sea.

Given the global influence of the Southern Ocean, any changes in the region would have widespread consequences. In particular, coupling between ocean circulation, sea ice and biogeochemical cycles can result in positive feedbacks that drive further climate change. Changes to the freshwater balance as result of changes in sea ice, precipitation, or ocean - ice shelf interaction may influence the strength of the overturning circulation. Reductions in sea ice extent 
will drive further warming through the ice - albedo feedback. Models suggest that the ability of the Southern Ocean to absorb carbon dioxide will decline with climate change, providing another positive feedback [32] and [48],

Changes in the physical and biogeochemical state of the Southern Ocean are in fact already underway. The circumpolar Southern Ocean is warming more rapidly than the rest of the global ocean [6], [19] and [20]. The upper layers of the Southern Ocean have freshened as the result of an increase in precipitation and melt of floating glacial ice [14]. Freshening of Antarctic Bottom Water (AABW) in the Indian and Pacific regions of the Southern Ocean may also reflect an increase in basal melt of floating glacial ice [1], [27], [28] and [45], with increased melt linked to increased heat flux from the ocean [42] and [53]. Widespread warming of AABW has been observed (e.g. [30], [31] and [64]); this is believed to be due to a combination of changes in formation properties, and changes in export processes driven by climate variability [36]. Since 1992, the satellite altimeter record shows an overall increase in sea level and strong regional trends linked to shifts in fronts of the ACC [55]). The average circumpolar extent of sea ice shows a small but significant increase during the satellite era (post-1978), due primarily to large regional increases in the Ross Sea sector that are partially compensated by large decreases west of the Antarctic Peninsula (where rates of decrease rival those seen in the Arctic [59]). The Ross Sea increases are due to changing meridional winds associated with the strengthening trend of the Southern Annular Mode, and an anthropogenic influence (ozone depletion) has been suggested as the cause [61]. While some coupled models suggest that the overall extent could increase as meltwater increases stratification and insulates the surface layer from warmer deeper water [65], the IPCC (Intergovernmental Panel on Climate Change) 4AR (Fourth Assessment) models suggest sea ice is likely to decline by about $30 \%$ by 2100 [66]. The recent small increase in Antarctic sea ice extent has been linked to the depletion of stratospheric ozone and significant declines in sea ice are likely in the future as ozone levels recover and the impact of increasing greenhouse gases is felt more strongly [61]. Models also suggest that sea ice thickness will decline more rapidly than ice extent, but we have no observations with which to assess whether sea ice thickness has changed.

The uptake of carbon dioxide by the ocean is changing the ocean's chemical balance by increasing the total inorganic carbon concentration, increasing the acidity and altering the carbon speciation [62]. The Southern
Ocean has been shown to be particularly sensitive to addition of CO2 [34] and [40]. There is some evidence that the changes are already causing a reduction in calcification of the shells of some organisms [37]. A common planktonic response to increased $\mathrm{CO} 2$ is an increase in primary productivity under higher $\mathrm{CO} 2$ (e.g. [60]) with changes to the elementary stoichiometry (e.g. [4]). Subsequent changes in the quantity and nutritional quality of primary production will have consequences for secondary production, food web carbon and energy flows and biogeochemical cycling. The impacts of changes in ocean chemistry on the Southern Ocean food web are largely unknown.

The Southern Ocean harbors unique and distinct ecosystems as a result of its isolation and extreme environment. Phytoplankton biomass is generally low, despite high concentrations of macronutrients, often ascribed to the lack of the micronutrient iron.. The Southern Ocean food web is characterized by a keystone species, Antarctic krill (Euphausia suberba), which supports large populations of higher predators. This dependence on a single species and the uniqueness of the Southern Ocean food webs and biogeochemical cycles make the system vulnerable to climate variability and change. For example, a decline in krill has been linked to a reduction in sea ice in the southwestern Atlantic [2]. There is fragmentary evidence of changes in other components of the Southern Ocean food web, from phytoplankton to penguins and seals [15] and [29]. However, most biological and ecological time series are short, incomplete and limited to a particular location, making it difficult to assess and interpret long-term trends. Often the physical and chemical measurements needed to link ecosystem variability to environmental variability do not exist.

In addition to climate effects, human pressures on the Southern Ocean are increasing and will likely to continue to do so. Antarctic tourism is a rapidly growing industry. Expanded exploitation of marine resources is likely as more traditional sources of protein decline or increase in cost. Increased use of the Southern Ocean will increase the need for an effective search and rescue capability, guided by the best available information on ocean conditions. Geoengineering solutions (e.g. iron fertilisation of the Southern Ocean) are being considered as mitigation strategies for $\mathrm{CO} 2$ removal. Increased use of the Southern Ocean will result in greater demand for knowledge to manage resources and to inform decisions by policy makers, industry and the community. 


\section{VISION FOR A SOUTHERN OCEAN OBSERVING SYSTEM}

The need to better understand global climate change and its impacts requires a Southern Ocean Observing System that is:

- Sustained,

- circumpolar, from the Subtropical Front to the Antarctic continent,

- multi-disciplinary (physics, biogeochemistry, sea ice, biology, surface meteorology),

- feasible and cost-effective,

- integrated with the global observing system,

- based initially on proven technology but evolves as technology develops,

- integrated with a data management system built on existing structures,

- able to deliver observations and products to a wide range of end-users.

- and builds on current and future research programs.

Research programs over the past 15 years have proved that sustained observations of the Southern Ocean are feasible and provided the scientific rationale underscoring the need and urgency for such observations. For example, the repeat hydrography program has quantified the evolving ocean inventory of heat and carbon, demonstrated that changes are occurring throughout the full depth of the Southern Ocean, and provided a platform for a wide suite of interdisciplinary observations. Satellites are providing circumpolar, year-round coverage of physical and biological variables and sea ice properties with high resolution in space and time. Moorings have provided time series of transports and water mass properties in critical regions. The development of autonomous profiling floats (Argo) has now allowed broad-scale, year-round measurements of the interior of the Southern Ocean to be made for the first time. The ocean beneath the sea ice, inaccessible with traditional platforms, is being measured with acoustically-tracked floats and miniaturised oceanographic sensors attached to marine mammals. Measurements of biological distributions and processes using net tows, continuous plankton recorders, and acoustics are providing new insights into the coupling of physical, biogeochemical and ecological processes. Autonomous underwater vehicles are providing new insight into the ocean beneath ice shelves.

These developments are a striking success, and go far beyond what was envisioned a decade ago during a pioneering community exercise to promote a sustained ocean observing system [43]. In particular, the emphasis then was on maintaining the traditional hydrographic, high-density XBT (Expendable Bathythermograph), and mooring arrays, and a call for Argo to include the Southern Ocean. We are beginning now to see the fruits of this effort in terms of upper ocean salinity observations by Argo and marine mammals and the likely determination of an enhanced freshwater cycle, with important changes occurring in the Southern Ocean. The need for traditional observations is just as strong now as then, and the sampling criteria have not changed. However, it is evident that there is an urgent need for greater integration of physical and biological observations, and an extension into the cryosphere where it overlaps with the ocean.

This community white paper summarizes the key points from the full SOOS (Southern Ocean Observing System) plan [56].

\section{STRATEGY}

Based on the rationale above, six key science challenges were identified that require sustained observations to be addressed:

1. The role of the Southern Ocean in the global heat and freshwater balance.

2. The stability of the Southern Ocean overturning circulation.

3. The stability of the Antarctic ice sheet and its contribution to sea-level rise,

4. The future of Southern Ocean carbon uptake.

5. The future of Antarctic sea ice and

6. Impacts of global change on Southern Ocean ecosystems.

The full SOOS plan [56] describes the combination of sustained observations needed to address each of these key science challenges. Here, we briefly summarise the main elements of SOOS. Each of these elements is ready now. The international effort during the International Polar Year demonstrated the readiness and feasibility of a comprehensive, integrated system of Southern Ocean observations.

\subsection{Repeat hydrography}

As in other basins, repeat hydrographic sections provide the backbone of a sustained observing system for the Southern Ocean. Repeat hydrography provides water samples for analysis of properties for which in situ sensors do not exist, the highest precision measurements for analysis of change and for 
calibration of other sensors, accurate baroclinic transport estimates, a platform for a wide range of ancillary measurements and the only means of sampling the full ocean depth [25]. CLIVAR (CLimate VARiability and Predictability project of the World Climate Research Programme) and the global carbon survey have re-occupied many of the sections occupied during the World Ocean Circulation Experiment (WOCE)

\subsubsection{Recommendations}

Figure 1 shows the WOCE/CLIVAR repeat hydrographic lines to be repeated as part of SOOS. Sections identified as high priority include quasi-zonal lines allowing exchange between the ACC belt and the subtropical and subpolar regimes to be measured and two or three meridional lines to sample the non-zonal variations in each basin. To document the changing inventory of heat, freshwater and carbon dioxide, the sections need to be repeated on a 5 to 7 year time-scale. Annual occupations of the Drake Passage line are needed. The transects should include measurements of physical (e.g. CTD (Conductivity-TemperatureDepth)/O2, Shipboard and Lowered Acoustic Doppler Current Profilers (SADCP/LADCP), tracers, oxygen18), biogeochemical (e.g. nutrients, trace elements and micronutrients, carbon, isotopic measurements of export flux, dimethyl sulphide (DMS)), and biological (e.g. primary production, pigments, bio-optics, fast repetition rate fluorometer, molecular diversity, biomarkers, targeted trawls, net tows, acoustic) variables. The sections should extend from north of the ACC to the Antarctic coast, including the sea ice zone and the continental slope and shelf (therefore the high latitude sections need to be done on ice-capable vessels). A new program of repeat CTD sections across the Antarctic slope and shelf by research and supply vessels travelling to and from Antarctic bases should be initiated to monitor evolution of shelf and bottom water properties and circulation, building on the efforts of the iAnZone/SASSI (international Antarctic Zone/ Synoptic Antarctic Shelf-Slope Interactions) program of the International Polar Year.

\subsection{Enhanced Southern Ocean Argo}

All of the key science challenges require sustained, broad-scale measurements of the ocean state, measurements that can only be obtained using autonomous platforms like profiling floats. A sustained commitment to maintenance of a profiling float array in the Southern Ocean is critical. Argo has made a particularly significant contribution to observations of remote areas like the Southern Ocean; already there are more profiles collected from Argo floats than from the entire history of ship-based oceanography in this region (Fig. 2). The float array needs to extend to seasonally ice-covered seas, through the use of ice-capable floats and acoustic tracking of floats.

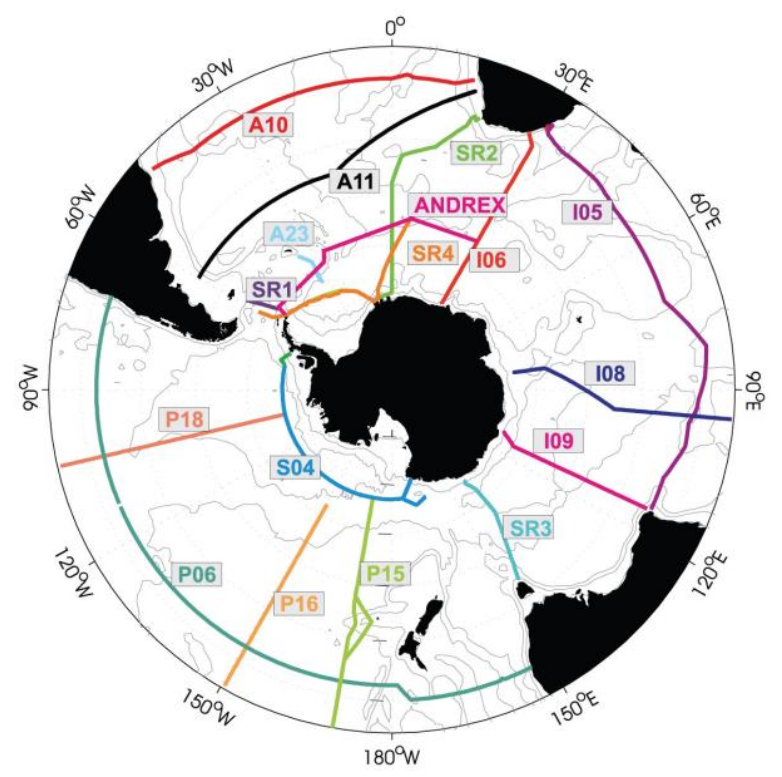

Figure 1: Repeat hydrographic sections to be occupied by SOOS.

\subsubsection{Recommendations}

The first priority is to maintain the Argo network at the nominal Argo density [46]. The extension of the system to sample under sea ice is also important, as some of the most important changes are occurring near the ice shelves and within the sea ice zone. Floats capable of deeper profiling would be of particular value in the Southern Ocean, where significant changes have been observed below $2000 \mathrm{~m}$. Oxygen sensors will provide useful information on ventilation processes and the carbon cycle. Sensors to measure a wider range of biological and chemical parameters (e.g. bio-optics) are needed to relate variations in the physical environment to biogeochemistry and ecosystem processes.

\subsection{Underway sampling from ships}

The full hydrographic sections need to be complemented by more frequent underway sampling transects to reduce aliasing of signals with time-scales shorter than the 5-7 year repeat cycle of the repeat hydrography (the issue of seasonal aliasing remains, as most underway measurements are made between October and March). While underway measurements are generally limited to the surface layer, use of ships of opportunity provide a cost-effective means of collecting a wide range of physical, biogeochemical and biological observations: temperature, salinity, velocity (from ADCP (Acoustic Doppler Current Profiler)), $\mathrm{pCO} 2, \mathrm{pH}$, nutrients, chlorophyll a, fast repetition rate fluorometry (FRRF), plankton (from 
CPR (Continuous Plankton Recorder)), pigments, surface meteorology and Expendable Bathythermographs and CTDs (XBTs/XCTDs) to provide measurements of upper ocean thermal structure along the ship track, including mixed layer depth (the Ocean Indien Service d'Observation, OISO, and SURVOSTRAL (Surveillance de l'Océan Austral or Monitoring the Southern Ocean) programs provide an example of what is required).. However, few ships at present measure this complete suite of variables. Aerosol sampling from ships is needed to quantify the aeolian input of iron and other trace elements to the Southern Ocean.

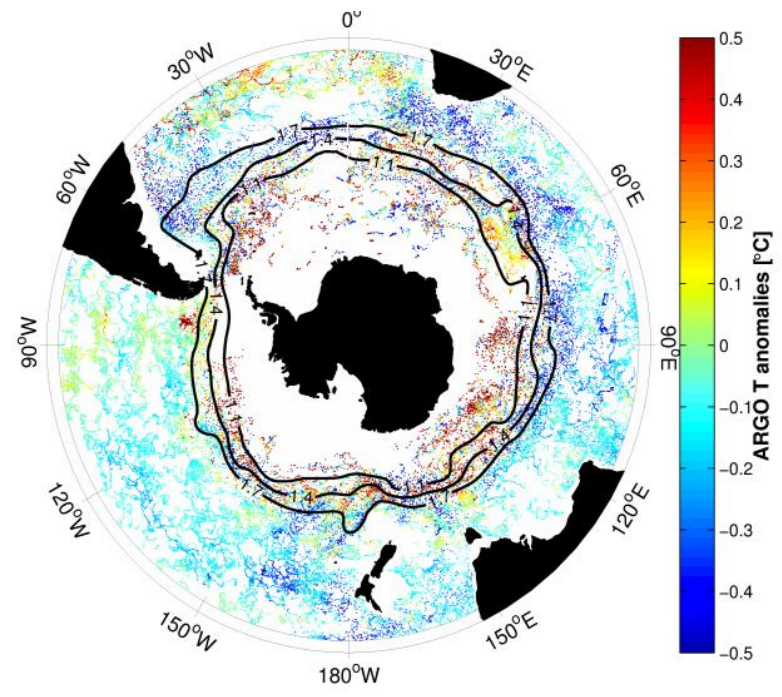

Figure 2: The dots show the distribution of 52,447 Argo profiles used to calculate the deviations of Argo potential temperatures averaged over the neutraldensity layer 26.9-27.7 from the climatological mean. Dark curves are contours of climatological dynamic height giving an approximate representation of ACC position. The plot indicates the coverage of the

Southern Ocean obtained in the first few years of the Argo program. (From [6[).

\subsubsection{Recommendations}

The present underway sampling system is shown in Fig. 3. There is a need to expand the fleet of ships making routine measurements of the Southern Ocean and to increase the number of variables measured on each line [21]. Antarctic resupply ships and tourist vessels remain underexploited. Autonomous sampling devices (e.g. Ferry Box [26]) should be installed on additional vessels. Upgrading the surface meteorology measurements made on these vessels is a high priority and will help improve the poorly known air-sea flux estimates over the Southern Ocean. A comprehensive review of requirements for monitoring changes to the global ocean-atmosphere carbon flux can be found in
[50]. Similarly, the observational network requirements for ocean acidification studies are presented in [17].

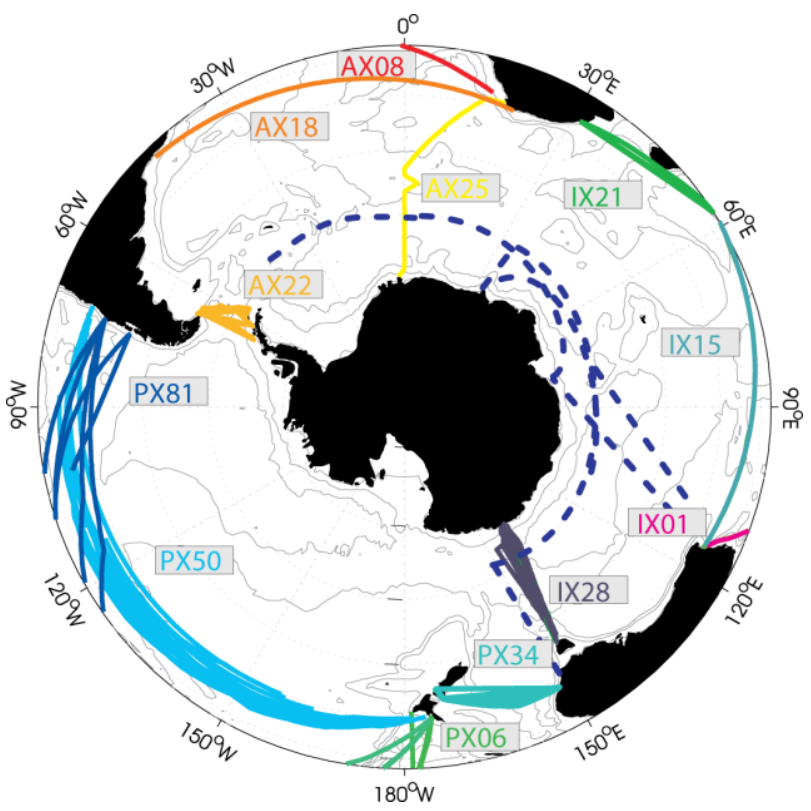

Figure 3: The existing ship-of-opportunity lines in the Southern Ocean

\subsection{Time-series stations and monitoring of key passages}

Several key passages and boundary currents in the Southern Ocean are high priorities for sustained observations because of their role in the global-scale ocean circulation (Fig. 4). Tide gauges and bottom pressure recorders have been shown to provide a cost effective means of monitoring the variability in the transport of the ACC on timescales from weeks to years [35]. Tide gauge data from the Antarctic coast and Southern Ocean islands form a critical part of the global sea-level observing system.

\subsubsection{Recommendations}

High priority regions for sustained moored measurements include Drake Passage, the Weddell Sea Convection Control (WECCON) and Goodhope experiments south of Africa and the locations of deep outflows (e.g. the western Weddell Sea and the deep boundary current on the eastern flank of the Kerguelen Plateau, the Princess Elizabeth trough, and the Ross Sea and Adelie Land bottom water outflows) [18], [22], [51] and [52]. The existing array of tide gauges and bottom pressure sensors needs to be maintained and extended to the western hemisphere. The Antarctic Slope Front and Antarctic Coastal Current make a significant contribution to interbasin exchange and therefore need to be measured on a sustained basis. Likewise, the Agulhas and Tasmanian limbs of the southern hemisphere "supergyre" [57] provide 
important interbasin connections with consequences for climate and therefore need to be monitored. Autonomous water samplers on moorings will be important for obtaining biogeochemical time series information.

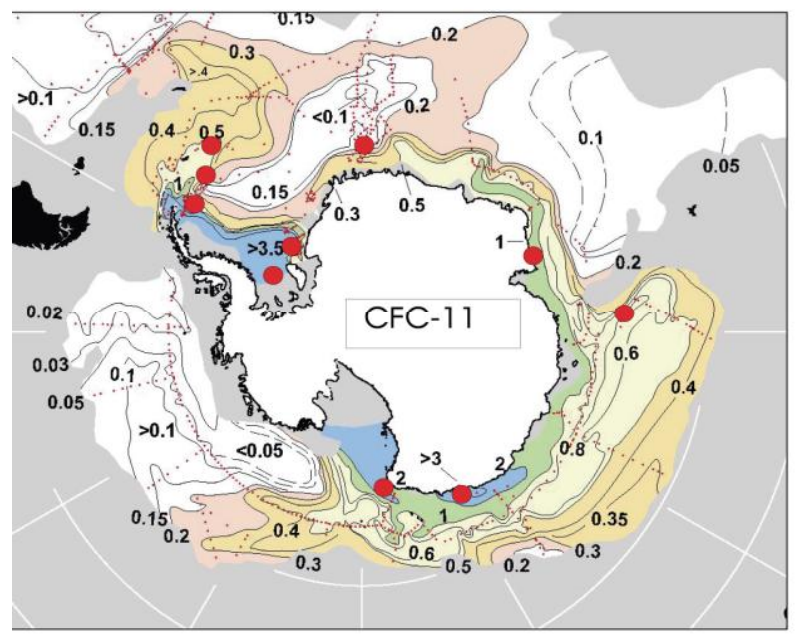

Figure 4: Map of proposed moored arrays to sample the primary Antarctic Bottom Water formation and export sites, as part of a coordinated global array to measure the deep limb of the global overturning circulation ([13] and [18]. The map shows the inventory of chlorofluorocarbon $11(C F C-11)$ in the density layer corresponding to $A A B W$ (from [41]).

\subsection{Animal-borne sensors}

Oceanographic sensors deployed on birds and mammals can make a significant contribution to SOOS in two ways: by relating predator movements and behaviour to fine-scale ocean structure [5] and [9], and by providing profiles of temperature and salinity from regions of the Southern Ocean that are difficult to sample by other means (e.g. beneath the winter sea ice; [10] and [12]).

\subsubsection{Recommendations}

Maintain the program of seal tag deployments established during IPY (International Polar Year) to provide information on seal foraging behaviour and its relationship to environmental variability and on the oceanographic conditions in the open ocean and in the sea ice zone in winter [11].

\subsection{Sea ice observations}

Measurements of both the extent and thickness (volume) of sea ice are needed to understand the role of Antarctica in the climate system. A variety of satellite instruments provide continuous, circumpolar observations of sea ice extent, with varying spatial resolution. Measuring sea ice volume, however, remains a significant challenge.

\subsubsection{Recommendations}

A variety of tools will need to be used to meet the challenge of providing sustained measurements of sea ice thickness and extent: AUV's (Autonomous Underwater Vehicles) and fixed-point moorings with ice-profiling sonars, acoustically-tracked floats with ice thickness sonars, ship-board observations including ice drift stations, remote sensing and data-assimilating models. The most critical observations to make are those that can be used to validate remote sensing measurements, as satellites provide the only means to sample sea ice over broad areas. A circumpolar "snapshot" of Antarctic sea ice thickness fields should be obtained as soon as possible to provide a baseline against which future change can be assessed. Two ships using an AUV to obtain "ice-edge to coast" transects could complete sixteen to twenty transects over the four-month winter period, consistent with the spatial sampling required to account for regional variability as assessed by the Antarctic Sea Ice Processes and Climate (ASPeCt) programme [63]. The AUV program will collect a variety of physical and biological data as well as ice thickness (e.g. salinity, temperature, currents, sonar for biology), and support on-ice process studies to help validate remote sensing products. Time series of ice thickness from fixed-point moorings are needed to complement the spatial sampling from the AUV program as well as more systematic collection of Antarctic sea ice thickness measurements, including ASPeCt observations and IceCam, from additional research, supply and tourist vessels. Recovery of historical Antarctic sea ice thickness data from individual investigators is essential for establishing a longer baseline of observations and a data portal has been established at the Australian Antarctic Data Centre for this purpose and for archiving all other data on Antarctic sea ice properties (http://data.aad.gov.au/aadc/seaice).

\subsection{Enhanced sea ice drifter array}

Our understanding of the intense and highly variable ocean - ice - atmosphere interactions taking place in the Antarctic sea ice zone is poor due to the lack of observations. Numerical weather predictions south of 60S suffer from a lack of surface pressure observations from the Sea Ice Zone (SIZ); as a consequence, flux products derived from reanalyses of the numerical weather prediction (NWP) models are also uncertain. An enhancement of the circumpolar array of sea ice buoys is needed to map sea ice drift around the whole of Antarctica, to complement efforts to measure sea ice thickness, and to improve southern hemisphere meteorological analyses. 


\subsubsection{Recommendations}

A basic array of 50 to 100 drifting buoys is needed to measure surface pressure and position. A smaller number of "mass balance buoys" will be used to measure ice and snow thickness, providing crucial ground-truth for new satellite sensors. Dense clusters of buoys will be deployed in some locations for detailed studies of ice dynamics and deformation.

\subsection{Ocean circulation under sea ice}

The ocean circulation and structure beneath the Antarctic sea ice remains largely unknown. New technologies now allow ocean currents and stratification beneath the sea ice to be observed for the first time. The strategy for sub-ice observations in the Antarctic will rely heavily on technology being developed for the Arctic: acoustic tracking of floats and gliders; acoustic communication links; ice-tethered profilers and listening/telemetry/sound source stations; ice thickness measurements from floats; animal-borne sensors; and ULS and current meter moorings. However, the challenges are significantly greater in the Antarctic. The area of the Antarctic sea ice pack is much greater than that of the Arctic; many areas are more remote; and the divergence and strong seasonality of the sea ice pack makes ice-tethered stations more difficult to maintain. Therefore, in the Antarctic efforts will need to focus on one or more "well-measured" regions or basins.

\subsubsection{Recommendations}

Maintain the array of sound sources and acousticallytracked floats established in the Weddell gyre during the IPY. Establish a similar system in the Ross Sea gyre. Expand the deployment of ice-capable floats (e.g. the Polar Profiler) in the Antarctic sea ice zone.

\subsection{Ocean - ice shelf interaction}

Basal melting and freezing on the undersides of floating ice shelves exert significant influences on the ocean close to the Antarctic margin. These processes impact strongly on shelf water characteristics and the dense precursors of Antarctic Bottom Water in locations such as the southern Weddell and Ross Seas (e.g. [27], [38] and [39], with a freshening of AABW observed in the Indian and Pacific Sectors of the Southern Ocean being attributed to enhanced basal melt [27], [28] and [45]. In West Antarctica, a marked deflation of parts of the ice sheet has been observed, ascribed to increased ocean temperatures impacting strongly on the ice shelves (e.g. [53]). However, despite their importance, ocean circulation and properties under shelf ice have been measured in only very few locations. Recent measurements beneath the Pine Island Glacier using the AUV Autosub are an exciting development, but sustained measurements are also needed, to track the impacts of ocean climate changes on the ice shelves, and the subsequent feedbacks.

\subsubsection{Recommendations}

Deploy and maintain oceanographic moorings beneath the Antarctic ice shelves in key strategic locations using hot water drilling technology. Coordinate work with geological science community where appropriate, to take advantage of drilling expeditions being conducted for sediment/sub-seabed research.

\subsection{Enhanced meteorological observations}

An enhanced atmospheric observing system is needed to improve Antarctic and southern hemisphere weather forecasts. The enhanced observations should include additional automatic weather stations and remote profilers, sea level pressure observations from ice and ocean drifters, flux reference stations and measurements from aircraft (manned and un-manned). Climate research benefits from improved weather forecasts in the increased accuracy of the flux products derived from NWP model reanalyses. The air-sea fluxes of heat and moisture are poorly known at high southern latitudes, making it difficult to diagnose the interactions between atmosphere, ocean and sea ice that lie at the heart of climate variability and change.

\subsubsection{Recommendations}

State-of-the-art meteorological sensors (e.g. Improved Meteorology (IMET) systems) should be installed on as many Antarctic research, supply and tourist ships as possible to provide validation data for the next generation of flux products from reanalyses and satellites [16]. Deployment of surface flux reference stations is a significant technical challenge in the high wind and sea state environment typical of the Southern Ocean, but is required to provide a data set to test flux products derived from satellite data and reanalyses. Pilot projects are being established south of Australia and in the Atlantic sector.

\subsection{Phytoplankton and primary production}

Sustained observations of phytoplankton biomass, species distributions and primary production are needed to relate environmental variability to biological activity. Ocean color satellites are critical as they provide the only circumpolar view of biological activity in the Southern Ocean. In situ measurements are needed to refine algorithms used to interpret the satellite data, to relate surface chlorophyll to columnintegrated production and for analysis of additional pigments and phytoplankton community composition. These measurements need to be sufficiently dense in 
the vertical to resolve the structure of the mixed layer and the waters immediately below.

\subsubsection{Recommendations}

Fluorescence, fast repetition rate fluorometry (FRRF) and pigment analyses are needed on a larger suite of underway vessels (research, supply and tourist ships). These observations should also be made in the upper ocean on each of the repeat hydrographic transects. Year-round sampling is needed, but difficult given the fact that both research and supply vessels tend to operate in the summer half of the year. This underscores the need for development of miniaturized low-power sensors for use on mobile platforms and moorings. Observations to quantify the progress and impact of ocean acidification are needed [17].

\subsection{Zooplankton and micro-nekton:}

Antarctic plankton are expected to be particularly sensitive and vulnerable to climate change. Global warming will affect sea ice patterns and plankton distributions. Increased UV (ultraviolet) levels, ocean acidification, invasive plankton species, pollution and harvesting impacts are also potential major threats. At this stage we do not know the synergistic effects of any of the threats acting in combination. Zooplankton sampling has in the past largely been carried out as part of focused, short-term experiments and has generally focused on distribution and abundance. Existing longterm sampling programs include the Japanese Antarctic Research Expedition (JARE) annual Norpac plankton net sampling, the US Antarctic Marine Living Resources (AMLR) program, the Palmer LTER, the British Antarctic Survey monitoring survey and the SCAR (Scientific Committee on Antarctic Research) Southern Ocean Continuous Plankton Recorder (SOCPR Survey). Gaps include a lack of winter data, lack of sampling in the sea ice zone, lack of data from the Pacific, and a lack of sampling at depths greater than $200 \mathrm{~m}$. The CPR, the primary tool used for broadscale sampling of zooplankton, samples the top $20 \mathrm{~m}$.

\subsubsection{Recommendations}

Maintain and expand the CPR survey, in particular to fill gaps in the Pacific sector and in winter. Use results from regional studies to design a zooplankton sampling plan that combines the broad spatial and temporal coverage of the CPR with other techniques (net tows, acoustics [23]) to fill gaps and assess potential biases (e.g. summer sampling, CPR limited to top $20 \mathrm{~m}$ ).

\subsection{Ecological monitoring:}

Observations of the distribution and abundance of top predators (fish, penguins, sea birds, seals and whales) can provide indications of changes in the ecosystem as a whole. Long-term monitoring programs have been established at a few sites around Antarctica including the Long Term Ecological Research (LTER) site on the western Antarctic peninsula and monitoring of landbased predators carried out by the Commission for the Conservation of Antarctic Marine Living Resources (CCAMLR) Ecosystem Monitoring Program (CEMP) (with most CEMP sites also located on the peninsula). Significant changes in e.g. penguin populations have been observed (e.g. [15] and [29]) in some locations, particularly on the western peninsula where the most dramatic environmental changes have been observed in recent decades. However, in many cases there is a lack of simultaneous physical and biogeochemical data to allow the causes of observed changes in higher trophic levels to be determined.

\subsubsection{Recommendations}

Maintain existing long-term monitoring programs of land-based predators and the neighboring marine environment (e.g. LTER and CEMP). Assess the benefit of enhancing the physical and biogeochemical observing system in the vicinity of long-term monitoring sites to add value to ecological time series.

\subsection{Remote sensing}

Access to high quality remote sensing data is particularly critical in the Southern Ocean, where in situ data is difficult to obtain. High priority satellite systems include radar and laser satellite altimetry, ocean colour, scatterometer, infrared and microwave sea surface temperature (SST), passive microwave, and synthetic aperture (SAR) [7], [8], [49] and [54]. Coordinated field campaigns and process studies are needed to improve algorithms for the interpretation of satellite measurements, in particular for ocean color and sea ice. This need has guided the SOOS plan for biology and sea ice observations [56].

\subsection{Data archaeology, management, archiving and access}

A critical element of SOOS is a data system that ensures both past and future data sets are accessible and of known quality. Given the lack of observations from the Southern Ocean, it is particularly critical that historical data is accessible and its quality assessed. Significant efforts have been made to do this for some physical oceanographic data, but many biological and sea ice data sets reside with the principal investigator. The compilation of zooplankton net tow data sets (KRILLBASE (Net-based databases of density and length frequency), [3]) provides an example of the value of this approach. The biogeochemical and ecological data sets need to be integrated with historical environmental data (e.g. hydrographic climatologies). A common data portal is needed to provide access to multi-disciplinary data sets (e.g. 
SCAR MarBIN (Marine Biodiversity Information Network)). SOOS needs to ensure that both past and future data sets are accessible.

\subsubsection{Recommendations}

Establish a SOOS data portal that provides easy access to multi-disciplinary data from the Southern Ocean. The SOOS data system will rely on existing data centers where possible (e.g. the CLIVAR \& Carbon Hydrographic Data Office (CCHDO) for hydrographic and tracer data, the thermal data assembly centers for XBT data, and the Argo data system). SOOS will facilitate recovery of biological and ecological data (e.g. net tows; acoustics; phytoplankton) and historical sea ice observations. Make effective use of National Antarctic Data Centres and SCAR's Standing Committee on Antarctic Data Management (SCADM), following the SCAR data and information strategy (when published in late 2009).

\subsection{Southern Ocean reanalysis}

Observations from SOOS will provide constraints for Southern Ocean state estimates and reanalysis [24] and [58]. The state estimates, in turn, will provide a dynamically consistent interpolation of sparse measurements.

\subsection{SOOS in 10 years}

The discussion above outlines a Southern Ocean Observing System that should start now, with existing technology. In ten years time, we envision an expanded SOOS that relies heavily on the use of autonomous sampling and includes:

- Profiling floats with additional sensors, depth range and longevity.

- Cost-effective, long-term, moored time series stations, measuring velocity and water properties, and transferring data using data capsule technology and telemetry.

- Gliders used routinely for monitoring key currents and water mass formation areas and under ice, including new low-power sensors to measure a range of biological and chemical properties.

- Sea ice (and snow) thickness delivered on a routine basis from satellite sensors, well-calibrated against a decade of in situ studies.

- Use of tags on multiple species to identify Southern Ocean hot (and cold) spots.

- Routine delivery of Southern Ocean state assessments and increasing use of reanalyses in the interpretation of observations.
- enhanced capacity to observe the Southern Ocean developed in additional countries.

- development of affordable, low-power, miniaturised sensors for biology and biogeochemistry for deployment on moored and mobile platforms (e.g. chlorophyll $a$, flow cytometers, fast repetition-rate fluorometers);.

\section{CONCLUSION}

Recent research has highlighted the global influence of Southern Ocean processes on ocean circulation, the climate system, and biogeochemical cycles, including the possibility of significant but poorly understood feedbacks. Sustained observations of the region are needed to address key research questions of direct relevance to society, including the global heat and freshwater balance, the stability of the overturning circulation, the future of the Antarctic ice sheet and its contribution to sea-level rise, the ocean uptake of carbon dioxide, the future of Antarctic sea ice, and the impacts of global change on Southern Ocean ecosystems. Advances in technology and understanding mean that it is now possible to design and implement a sustained, feasible and cost-effective observing system for the Southern Ocean to meet this need.

\section{REFERENCES}

1. Aoki, S., Rintoul, S.R., Ushio, S., Watanabe, S. and Bindoff, N.L. (2005). Freshening of the Adélie Land Bottom Water near $140^{\circ}$ E. Geophysical Research Letters, 32(L23601) doi:10.1029/2005GL024246.

2. Atkinson, A., Siegel, V., Pakhomov, E. and Rothery, P., (2004). Long-term decline in krill stock and increase in salps within the Southern Ocean. Nature, 432: 100-103.

3. Atkinson A, Siegel V, Pakhomov EA, Jessopp MJ, Loeb V (2009). A re-appraisal of the total biomass and production of Antarctic krill. Deep-Sea Res I 56:727740.

4. Bellerby R. G. J., Schulz K. G., Riebesell U., Neill C., Nondal G., Heegaard E., Johannessen T., and Brown K. R., (2008). Marine ecosystem community carbon and nutrient uptake stoichiometry under varying ocean acidification during the PeECE III experiment. Biogeosciences, 5, 1517-1527

5. Biuw, M., L. Boehme, C. Guinet, M. Hindell, D. Costa, J. B. Charrassin, F. Roquet, F. Bailleul, M. Meredith, S. Thorpe, Y. Tremblay, B. McDonald, Y. H. Park, S. R. Rintoul, N. Bindoff, M. Goebel, D. Crocker, P. Lovell, J. Nicholson, F. Monks, and M. A. Fedak. (2007). Variations in behavior and condition of a Southern Ocean top predator in relation to in situ oceanographic conditions. Proceedings of the National Academy of Sciences of the United States of America 104:1370513710. 
6. Böning, C. W., A. Dispert, M. Visbeck, S. R. Rintoul, and F. Schwarzkopf (2008). The response of the Antarctic Circumpolar Current to recent climate change, Nature Geoscience, 1, 864-869.

7. Bourassa, M. \& Co-Authors (2010). "Remotely Sensed Winds and Wind Stresses for Marine Forecasting and Ocean Modeling" in these proceedings (Vol. 2), doi:10.5270/OceanObs09.cwp.08.

8. Breivik, L. \& Co-Authors (2010). "Remote Sensing of Sea Ice" in these proceedings (Vol. 2), doi:10.5270/OceanObs09.cwp.11.

9. Burns, J. M., D. P. Costa, M. A. Fedak, M. A. Hindell, C. J. A. Bradshaw, N. J. Gales, B. McDonald, S. J. Trumble, and D. E. Crocker (2004). Winter habitat use and foraging behavior of crabeater seals along the Western Antarctic Peninsula. Deep Sea Research Part II: Topical

Studies in Oceanography 51:2279-2303.

10. Charrassin, J. B., M. Hindell, S. R. Rintoul, F. Roquet, S. Sokolov, M. Biuw, D. Costa, L. Boehme, P. Lovell, R. Coleman, R. Timmermann, A. Meijers, M. Meredith, Y. H. Park, F. Bailleul, M. Goebel, Y. Tremblay, C. A. Bost, C. R. McMahon, I. C. Field, M. A. Fedak, and C. Guinet (2008). Southern Ocean frontal structure and sea-ice formation rates revealed by elephant seals. Proceedings of the National Academy of Sciences 105:11634-11639\%R 11610.11073/pnas.0800790105.

11. Charrassin, J. \& Co-Authors (2010). "New Insights into Southern Ocean Physical and Biological Processes Revealed by Instrumented Elephant Seals" in these proceedings (Vol. 2), doi:10.5270/OceanObs09.cwp.15..

12. Costa, D. P., J. M. Klinck, E. E. Hofmann, M. S. Dinniman, and J. M. Burns (2008). Upper ocean variability in West Antarctic Peninsula continental shelf waters as measured using instrumented seals. Deep Sea Research Part II: Topical Studies in Oceanography 55:323-337.

13. Cunningham, S. \& Co-Authors (2010). "The Present and Future System for Measuring the Atlantic Meridional Overturning Circulation and Heat Transport" in these proceedings (Vol. 2), doi:10.5270/OceanObs09.cwp.21.

14. Curry, R., B. Dickson and Yashayaev, I. (2003). A change in the freshwater balance of the Atlantic Ocean over the past four decades. Nature, 426: 826-829.

15. Ducklow, H. W. et al., (2007). Marine pelagic ecosystems: the Western Antarctic Peninsula. Phil. Trans. R. Soc. B. 362, 67-94.

16. Fairall, C. \& Co-Authors (2010). "Observations to Quantify Air-Sea Fluxes and their Role in Climate Variability and Predictability" in these proceedings (Vol. 2), doi:10.5270/OceanObs09.cwp.27.

17. Feely, R. \& Co-Authors (2010). "An International Observational Network for Ocean Acidification" in these proceedings (Vol. 2), doi:10.5270/OceanObs09.cwp.29.
18. Garzoli, S. \& Co-Authors (2010). "Progressing Towards Global Sustained Deep Ocean Observations" in these proceedings (Vol. 2), doi:10.5270/OceanObs09.cwp.34.

19. Gille, S.T., 2002. Warming of the Southern Ocean Since the 1950s. Science, 295: 1275-1277.

20. Gille, S.T., 2008. Decadal-scale temperature trends in the Southern Hemisphere Ocean. Journal of Climate, 21, 4749-4765.

21. Goni, G. \& Co-Authors (2010). "The Ship of Opportunity Program" in these proceedings (Vol. 2), doi:10.5270/OceanObs09.cwp.35.

22. Gordon, A. \& Co-Authors (2010). "Interocean Exchange of Thermocline Water: Indonesian Throughflow; "Tassie" Leakage; Agulhas Leakage" in these proceedings (Vol. 2), doi:10.5270/OceanObs09.cwp.37.

23. Handegard, N. \& Co-Authors (2010). "Toward a Global Ocean Ecosystem Mid-Trophic Automatic Acoustic Sampler (MAAS)" in these proceedings (Vol. 2), doi:10.5270/OceanObs09.cwp.40.

24. Heimbach, P. \& Co-Authors (2010). "Observational Requirements for Global-Scale Ocean Climate Analysis: Lessons from Ocean State Estimation" in these proceedings (Vol. 2), doi:10.5270/OceanObs09.cwp.42.

25. Hood, M. \& Co-Authors (2010). "Ship-Based Repeat Hydrography: A Strategy for a Sustained Global Program." in these proceedings (Vol. 2), doi:10.5270/OceanObs09.cwp.44.

26. Hydes, D. \& Co-Authors (2010). "The Way Forward in Developing and Integrating Ferrybox Technologies" in these proceedings (Vol. 2), doi:10.5270/OceanObs09.cwp.46.

27. Jacobs, S.S. (2004). Bottom water production and its links with the thermohaline circulation. Antarctic Science 16 (4): 427-437.

28. Jacobs, S. S. (2006). Observations of change in the Southern Ocean. Phil. Trans. Roy. Soc. A, 364, 16571681, doi:10.1098/rsta.2006.1794.

29. Jenouvrier, S; Weimerskirch, H; Barbraud, C, et al. (2005). Evidence of a shift in the cyclicity of Antarctic seabird dynamics linked to climate. Proc. Roy. Soc. BBiol. Sci. 272, 887-895.

30. Johnson, GC; Doney, SC (2006). Recent western south Atlantic bottom water warming. Geophys. Res. Lett., 33, L14614.

31. Johnson, GC; Purkey, SG; Bullister, JL (2008). Warming and Freshening in the Abyssal Southeastern Indian Ocean. J. Clim. 21, 5351-5363.

32. Le Quéré, C. Christian Rödenbeck, Erik T. Buitenhuis, Thomas J. Conway, Ray Langenfelds, Antony Gomez, Casper Labuschagne, Michel Ramonet,

TakakiyoNakazawa, Nicolas Metzl, Nathan Gillett, Martin Heimann (2007). Saturation of the Southern Ocean CO2 Sink Due to Recent Climate Change. Science 316, 1735 - 1738, doi:10.1126/science.1136188. 
33. Levitus, S., Antonov, J. and Boyer, T., 2005. Warming of the world ocean, 1955-2003. Geophysical Research Letters, 32(2): doi:10.1029/2004GL021592.

34. McNeil BI and Matear, RJ , (2008) Southern Ocean acidification: A tipping point at 450-ppm atmospheric CO2. Proc. Nat. Acad. Sciences USA, 105, 1886018864.

35. Meredith, M.P., P.L. Woodworth, C.W. Hughes and V. Stepanov (2004). Changes in the ocean transport through Drake Passage during the 1980s and 1990s, forced by changes in the Southern Annular Mode. Geophysical Research Letters, 31(21), L21305, doi:10.1029/2004GL021169.

36. Meredith, MP; Murphy, EJ; Hawker, EJ, et al. (2008). On the interannual variability of ocean temperatures around South Georgia, Southern Ocean: Forcing by El Nino/Southern Oscillation and the Southern Annular Mode. Deep-Sea Research II, 55, 2007-2022.

37. Moy, A.D., Howard, W.R., Bray, S.G. \& Trull T.W., 2009. Reduced calcification in modern Southern Ocean planktonic foraminifera. Nature Geoscience doi:10.1038/ngeo460.

38. Nicholls, K.W., and A. Jenkins, Temperature and Salinity beneath Ronne Ice Shelf, Antarctica, Journal of Geophysical Research, 98, 22553-22568, 1993.

39. Nicholls, K.W. and K. Makinson, (1998). Ocean circulation beneath the western Ronne IceShelf, as derived from in situ measurements of water currents and properties, in Ocean, Ice, and Atmosphere: Interactions at the Antarctic Continental Margin, edited by S.S. Jacobs, and R.F. Weiss, pp. 301-318, AGU, Washington D.C., 1998.

40. Orr, J. C., V. J. Fabry, O. Aumont, L. Bopp, S. C. Doney, R. A. Feely, A. Gnanadesikan, N. Gruber, A. Ishida, F. Joos, R. M. Key, K. Lindsay, E. Maier-Reimer, R. Matear, P. Monfray, A. Mouchet, R. G. Najjar, G.-K. Plattner, K. B. Rodgers, C. L. Sabine, J. L. Sarmiento, R. Schlitzer, R. D. Slater, I. J. Totterdell, M.-F. Weirig, Y. Yamanaka, and A. Yool (2005). Anthropogenic ocean acidification over the twenty-first century and its impact on calcifying organisms. Nature. 437: 681-686.

41. Orsi, A.H., G. C. Johnson and J. B. Bullister (1999). Circulation, mixing and production of Antarctic Bottom Water. Prog. Oceanog. 43, 55-109.

42. Rignot, E; Bamber, JL; Van Den Broeke, MR, et al., (2008). Recent Antarctic ice mass loss from radar interferometry and regional climate modelling. Nature Geoscience, 1, 106-110.

43. Rintoul, S. R., J. Church, E. Farhbach, M. Garcia, A. Gordon, B. King, R. Morrow, A. Orsi, and K. Speer, (2002). Monitoring and understanding Southern Ocean variability and its impact on climate: A strategy for sustained observations. In: Observing the Ocean in the 21st Century, C. J. Koblinsky and N. R. Smith (Eds.), Bureau of Meteorology, Melbourne, Australia, pp. 486508.
44. Rintoul, S. R., C. Hughes and D. Olbers, 2001. The Antarctic Circumpolar System. In: Ocean Circulation and Climate, G. Siedler, J. Church, and J. Gould, (Eds.), Academic Press, 271-302.

45. Rintoul, S.R., 2007. Rapid freshening of Antarctic Bottom Water formed in the Indian and Pacific oceans. Geophysical Research Letters, 34(L06606): doi:10.1029/2006GL028550.

46. Roemmich, D. \& Co-Authors (2010). "Integrating the Ocean Observing System: Mobile Platforms" in these proceedings (Vol. 1), doi:10.5270/OceanObs09.pp.33.

47. Sabine, CL; Feely, RA; Gruber, N, et al., 2004. The oceanic sink for anthropogenic CO2, Science, 305, 367 371.

48. Sarmiento, JL; Gruber, N; Brzezinski, MA, et al., 2004. High-latitude controls of thermocline nutrients and low latitude biological productivity. Nature, 427, 56-60.

49. Scott, R. \& Co-Authors (2010). "Satellite Altimetry and Key Observations: What We've Learned, and What's Possible with New Technologies" in these proceedings (Vol. 2), doi:10.5270/OceanObs09.cwp.76.

50. Monteiro, P. \& Co-Authors (2010). "A Global Sea Surface Carbon Observing System: Assessment of Changing Sea Surface CO2 and Air-Sea CO2 Fluxes" in these proceedings ( Vol. 2), doi:10.5270/OceanObs09.cwp.64

51 Send, U. \& Co-Authors (2010). "OceanSITES" in these proceedings (Vol. 2), doi:10.5270/OceanObs09.cwp.79.

52. Send, U. \& Co-Authors (2010). "A Global Boundary Current Circulation Observing Network" in these proceedings (Vol. 2), doi:10.5270/OceanObs09.cwp.78.

53. Shepherd, A., D. Wingham and E. Rignot (2004). Warm ocean is eroding West Antarctic ice sheet. Geophys. Res. Lett. 31, L23402, doi:10.1029/2004GL021106.

54. Shum, C. \& Co-Authors (2010). "Geodetic Observations of the Ocean Surface Topography, Geoid, Currents, and Changes in Ocean Mass and Volume" in these proceedings (Vol. 2), doi:10.5270/OceanObs09.cwp.80.

55. Sokolov, S., and S. R. Rintoul (2009), Circumpolar structure and distribution of the Antarctic Circumpolar Current fronts: 2. Variability and relationship to sea surface height, J. Geophys. Res., 114, C11019, doi:10.1029/2008JC005248.

56. SOOS (Southern Ocean Observing System), 2010. www.clivar.org/organization/southern/expertgroup.

57. Speich, S., B. Blanke, P. de Vries, S. Drijfhout, K. Döös, A. Ganachaud, and R. Marsh (2002), Tasman leakage: A new route in the global ocean conveyor belt, Geophys. Res. Lett., 29(10), 1416, doi:10.1029/2001GL014586..

58. Stammer, D. \& Co-Authors (2010). "Ocean Information Provided Through Ensemble Ocean Syntheses" in these proceedings (Vol. 2), doi:10.5270/OceanObs09.cwp.85.

59. Stammerjohn SE, Martinson DG, Smith RC, Yuan X, Rind D (2008) Trends in Antarctic annual sea ice 
retreat and advance and their relation to El NinoSouthern Oscillation and Southern Annular Mode variability. Journal of Geophysical ResearchOceans, 113, C03S90.

60. Tortell, P. D., C. D. Payne, Y. Li, S. Trimborn, B. Rost, W. O. Smith, C. Riesselman, R. B. Dunbar, P. Sedwick, and G. R. DiTullio (2008), CO2 sensitivity of Southern Ocean phytoplankton, Geophys. Res. Lett., 35, L04605, doi:10.1029/2007GL032583.

61. Turner, J., J. C. Comiso, G. J Marshall, T. A. LachlanCope, T. Bracegirdle, T. Maksym, M. P. Merideth, Z. Wang, and A. Orr (2009). Non-annular atmospheric circulation change induced by stratospheric ozone depletion and its role in the recent increase of Antarctic sea ice extent, Geophys. Res. Lett., 36, L08502.

62. Vázquez-Rodríguez M., Touratier F., Lo Monaco C., Waugh D., Padin X.A., Bellerby R.G.J., Goyet C., Metzl N., Ríos A.F., Pérez F.F., (2009). Anthropogenic carbon in the Atlantic Ocean: comparison of four databased calculation methods, Biogeosciences, 6, 439-451.

63. Worby, AP; Geiger, CA; Paget, MJ, et al. 2008. Thickness distribution of Antarctic sea ice, Journal of Geophysical Research - Oceans, 113, C05S92.

64. Zenk, W; Morozov, E (2007). Decadal warming of the coldest Antarctic Bottom Water flow through the Vema Channel. Geophys. Res. Lett. 34, L14607.

65. Zhang, JL (2007). Increasing Antarctic sea ice under warming atmospheric and oceanic conditions, Journal of Climate, 20, 2515-2529.

66. Bracegirdle, T.J., Connolley, W.M. and Turner, J., 2008. Antarctic climate change over the twenty first century. Journal of Geophysical Research, 113(D03103): 10.1029/2007JD008933. 